\title{
The Synthesis and Characterization of Nickel and Cobalt Ferrite Nanopowders Obtained by Different Methods
}

\author{
Ilmars Zalite, Gundega Heidemane, Janis Grabis and \\ Mikhail Maiorov
}

Additional information is available at the end of the chapter

http://dx.doi.org/10.5772/intechopen.76809

\begin{abstract}
The single-phase $\mathrm{NiFe}_{2} \mathrm{O}_{4}$ and $\mathrm{CoFe}_{2} \mathrm{O}_{4}$ ferrites were synthesized by four methods: the high-frequency plasma chemical synthesis ("plasma"), sol-gel self-propagating combustion method ("combust"), and co-precipitation technology, combined with the hydrothermal synthesis ("hydrotherm") or spray-drying ("spray"). The specific surface area (SSA), crystallite size, and magnetic properties of the synthesized products have been determined. The synthesized ferrites are nanocrystalline single-phase materials with crystallite size of 5-40 nm. The SSA of nanoparticles synthesized in plasma is $28-30 \mathrm{~m}^{2} / \mathrm{g}$, the particle size distribution is in the range of 10-100 nm, with some individual particles up to $200 \mathrm{~nm}$. The SSA of the ferrites obtained by the self-combustion and hydrothermal synthesis is 40 \pm 3 and $60 \pm 5 \mathrm{~m}^{2} / \mathrm{g}$, respectively. The SSA of the samples obtained by the spray-drying method is $80-90 \mathrm{~m}^{2} / \mathrm{g}$, and the calculated particle size is $13-15 \mathrm{~nm}$. In this process, pellets up to $10 \mu \mathrm{m}$ are obtained. After synthesis, $\mathrm{CoFe}_{2} \mathrm{O}_{4}$ are characterized by the saturation magnetization $\mathrm{M}_{\mathrm{s}}$ of $75 \mathrm{emu} / \mathrm{g}$ ("plasma"), $53 \mathrm{emu} / \mathrm{g}$ ("combust") and $57 \mathrm{emu} / \mathrm{g}$ ("hydrotherm"). The $\mathrm{M}_{\mathrm{s}}$ of $\mathrm{NiFe} 2 \mathrm{O} 4$ is 44,29 , and $30 \mathrm{emu} / \mathrm{g}$, respectively. The products obtained by the spray-drying method are partially $\mathrm{X}$-ray amorphous and show magnetic properties only after heating above $450^{\circ} \mathrm{C}$. These nanopowders were used in sintering studies.
\end{abstract}

Keywords: $\mathrm{NiFe}_{2} \mathrm{O}_{4^{\prime}} \mathrm{CoFe}_{2} \mathrm{O}_{4^{\prime}}$ nanoparticles, synthesis, properties

\section{Introduction}

Ferrites are a wide range of minerals and synthetic materials, which have attracted a wide range of scientists' interest due to their various applications. Ferrites are technologically significant 
materials due to their unique electrical, dielectric, electronic, mechanical, magnetic, optical and catalytic properties. These ferrites are characterized by good magnetic properties [1], low $\left(\mathrm{NiFe}_{2} \mathrm{O}_{4}\right)$ [2] or high $\left(\mathrm{CoFe}_{2} \mathrm{O}_{4}\right)$ [3] magnetic coercivity, high electrical resistivity and negligible eddy current loss for high-frequency electromagnetic wave propagation [2], chemical stability and fairly high mechanical hardness [4], low dielectric losses and high Curie temperature [5]. $\mathrm{CoFe}_{2} \mathrm{O}_{4}$ has a high permeability in the radio frequency range [6], high thermal stability [7], moderate saturation magnetization [3] and electrical conductivity [8].

The most significant and most popular use of ferrites is in optics, electronics, mechanics and other technical fields [9]. Ferrites also play a major role in medicine, biomedical applications, as chemical catalysis and special coatings (antistatic, electromagnetic shielding). Scientific articles contain extensive information on hyperthermia. This method introduces ferrite nanoparticles into living organisms and, under controlled conditions, nanoparticles are transported to the cancerous areas of the body, and cancer cells are destroyed in a magnetic field by heat treatment [10].

Ferrites have become suitable for many technological applications such as microwave devices [11] and telecommunication devices, electric motors and generators, as excellent core material for power transformers in electronics, antenna rods, loading coils and read/write heads for high speed digital tape [1], tape recorders and discs [3], high-density information storage and recording devices and as permanent magnets [11], sensors [12], and so on. Magnetic nanoparticles and in particular magnetic fluids (ferrofluids) are particularly important in biotechnology and biomedicine - the supply of biomedical drugs and as contrast media [12], in medical diagnostics [13]. Ferrite materials are widely used in catalysts [12]. In recent years, ferrite materials have been used to prevent and eliminate radio frequency interference in audio systems [4], as polarized ferroelectric ceramics in acoustic elements in underwater converters [14] and microwave absorbing materials [15], including ferrite-containing radar absorbing paints for masking military aircraft [16]. Lately, it has been discovered that cobalt ferrite nanoparticles can also act as photomagnetic material that shows interesting light-induced coercivity changes [17].

Ferrites in a nanocrystalline state (i.e., below single domain sizes [9]) are often found to have unique physical and mechanical properties compared to coarse-grained polycrystalline materials [18]. It is known that the properties of nanocrystalline ferrite materials, including dielectric constant, conductivity, permeability, and other magnetic properties are determined by their microstructure [19], which, in turn, is influenced by the method of their production [8], that is, the synthesis methods [1]. It is well known that the microstructure, in particular the crystallite size, essentially determines the parameters of the hysteresis loop of soft ferromagnetic materials [20]. Samples obtained with different synthesis methods show different electrical and magnetic properties [4]. Therefore, many new nanoparticle production techniques have been developed in recent years.

Ferrites, as the majority of ceramic materials, are obtained by reactions of solid phase from various oxides [21]. The development of nanotechnological processes has resulted in the development of several liquid phase and gas phase synthesis methods-chemical co-precipitation 
method [22], the sol-gel method [23], combustion reaction synthesis [24], hydrolysis [25], hydrothermal synthesis [26], salt melt technique [6], pyrolysis, various microwave synthesis methods [1] including microwave refluxing [27], microwave plasma [28] and microwave hydrothermal methods [29], high energy ball milling techniques [30], microemulsion methods [31], sono-chemical reactions [32], vapor deposition [33], precursor methods [34] and plasma synthesis [35].

In this work, we have tried to summarize our research results on ferrite nanoparticles produced by different methods and to compare their properties, including magnetic properties.

\section{Experimental procedure}

In research, nickel and cobalt ferrite nanopowders are obtained by the chemical sol-gel self-propagating combustion ("combust.") method [36], the co-precipitation technology in combination with hydrothermal synthesis ("hydrotherm.") [37] or spray-drying ("spray") [38] method and high-frequency plasma chemical synthesis ("plasma") [39]. The obtained nanopowders have been studied for mechanical and magnetic properties.

The synthesis of cobalt and nickel ferrites by the sol-gel self-propagating combustion method was carried out using reagent grade chemicals: $\mathrm{Co}\left(\mathrm{NO}_{3}\right)_{2} \cdot 6 \mathrm{H}_{2} \mathrm{O}, \mathrm{Ni}\left(\mathrm{NO}_{3}\right) \cdot 6 \mathrm{H}_{2} \mathrm{O}$, $\mathrm{Fe}\left(\mathrm{NO}_{3}\right)_{3} \cdot 9 \mathrm{H}_{2} \mathrm{O}$, glycine, nitric acid [36]. A $100 \mathrm{ml} 0.1 \mathrm{M}$ cobalt (or nickel) nitrate solution was added to a $200 \mathrm{ml} 0.1 \mathrm{M}$ iron nitrate solution. The glycine was separately dissolved in $100 \mathrm{ml}$ of distilled water, nitric acid added and both added to the nitrate mixture. Glycine (Gly) was used as a self-combustion agent with a molar ratio Me/Gly $=1: 0.8$ and Gly/Nitr. = 1:4. The mixture was evenly stirred until the mixture has congealed. Then the mixture was heated until it ignited, and the heating was continued at $300^{\circ} \mathrm{C}$ for $4 \mathrm{~h}$.

By the co-precipitation method, cobalt and nickel ferrites were synthesized using reagent grade chemicals: $\mathrm{FeCl}_{3} \cdot 6 \mathrm{H}_{2} \mathrm{O}$, urea, $\mathrm{Co}\left(\mathrm{NO}_{3}\right)_{2} \cdot 6 \mathrm{H}_{2} \mathrm{O}$ or $\mathrm{Ni}\left(\mathrm{NO}_{3}\right)_{2} \cdot 6 \mathrm{H}_{2} \mathrm{O}, \mathrm{NaOH}$ [37]. The precursor was obtained as follows: urea was hydrolyzed for $3 \mathrm{~h}$ in a $\mathrm{FeCl}_{3} \cdot 6 \mathrm{H}_{2} \mathrm{O}$ solution (molar ratio of $3: 1$ ) at $70-75^{\circ} \mathrm{C}$. Cobalt or nickel nitrate was added the cooled reaction mixture. The molar ratio $\mathrm{FeCl}_{3} \cdot 6 \mathrm{H}_{2} \mathrm{O}: \mathrm{Co}\left(\mathrm{NO}_{3}\right)_{2} \cdot 6 \mathrm{H}_{2} \mathrm{O}$ or $\mathrm{Ni}\left(\mathrm{NO}_{3}\right)_{2} \cdot 6 \mathrm{H}_{2} \mathrm{O}$ corresponds to the metal ion stoichiometry in ferrite. Continually stirring the suspension with $40 \% \mathrm{NaOH}$ solution, cobalt or nickel hydroxide was slowly precipitated until the $\mathrm{pH}$ of the suspension reached 9-10. Then the suspension was placed in an ultrasonic bath for $20 \mathrm{~min}$ and then treated for $24 \mathrm{~h}$ at $40^{\circ} \mathrm{C}$. The sediment was then washed with distilled water by decantation until the presence of $\mathrm{Cl}$ ions was no longer detected. Next are two processing options:

A. by the hydrothermal method, the volume of the hydroxides mixture is reduced by decanting to $250 \mathrm{ml}$, poured into the reaction vessel and placed in an autoclave. The hydroxide mixture was then treated hydrothermally at different temperatures $\left(200-250^{\circ} \mathrm{C}, 1-3 \mathrm{~h}\right.$, $\mathrm{p}=17-17.5 \mathrm{MPa})$. After hydrothermal treatment, the formed precipitate was filtered with a water jet pump using a $5 \mu \mathrm{m}$ membrane filter and washed with distilled water and dried at $40^{\circ} \mathrm{C}$; 
B. for spraying the hydroxide mixture with the spray-drying method, the pelleting machine was used developed by RTU Institute of Inorganic Chemistry. Main parameters of the suspension spray: hot air temperature and consumption of $370^{\circ} \mathrm{C}$ and $24 \mathrm{~m} / \mathrm{h}$, temperature in evaporating chamber $120-130^{\circ} \mathrm{C}$.

Technological equipment developed by the Institute of Inorganic Chemistry of the Riga Technical University [35] was used for the production of ferrites by means of high-frequency (HF) plasma chemical synthesis. Commercial metals and metal oxides ( $\mathrm{Ni}, \mathrm{Co}, \mathrm{NiO}, \mathrm{CoO}$ and $\mathrm{FeO}$ ) powders were evaporated in HF plasma to obtain ferrites. All raw materials in stoichiometric ratios (to obtain $\mathrm{NiFe}_{2} \mathrm{O}_{4}$ and $\mathrm{CoFe}_{2} \mathrm{O}_{4}$ ) were injected into nitrogen plasma at an average temperature of $5800-6200 \mathrm{~K}$. After evaporation of the raw materials, the vapor was cooled very quickly with the cooling gas (air) and the product condensed on the filter in the form of nanosized ferrite particles.

Ferrite nanopowders for sintering were prepared as follows: the ferrite nanopowder samples were mechanically mixed for $1 \mathrm{~h}$ in a planetary mill with $3 \%$ by weight of stearic acid (400 rpm, $\mathrm{ZrO}_{2}$ container, $\mathrm{ZrO}_{2}$ ball material) using isopropanol as a dispersing medium. Stearic acid was used for better pressing. After mixing, the samples were dried in an oven at $80^{\circ} \mathrm{C}$ and sieved through a $200 \mu \mathrm{m}$ sieve. For sintering without pressure samples were pressed (200 MPa) as tablets with a diameter of $12 \mathrm{~mm}$ and a height of 4-6 mm. Stearic acid was burned out at $600^{\circ} \mathrm{C}$. Samples were sintered at $900-1300^{\circ} \mathrm{C}$ in an air atmosphere at a rate of $10^{\circ} \mathrm{C} / \mathrm{min}$ in an oven LHT-08/18 (Nabertherm $\mathrm{GmbH}$ ) for $2 \mathrm{~h}$.

All samples were analyzed using the X-ray diffractometer Advance 8 (Bruker AXS). The size of the crystallites was calculated using the Scherer's equation. The magnetic properties of the synthesized ferrites were analyzed using vibrating sample magnetometry (VSM Lake Shore Cryotronics, Inc., Model 7404 VSM). The SSA was measured using the BET single point method. The size and morphology of the particles as well as the microstructure of the sintered material were studied using transmission electron microscope JEM-100S (JEOL) and a scanning electron microscope Mira/Tescan and Tescan Lyra-3 on the fracture surfaces. The density and open porosity of the sintered samples were determined by the Archimedes method.

\section{Results}

The characteristics of synthesized ferrites are given in Table $\mathbf{1}$ and Figures $\mathbf{1 - 5}$. It has been found that all synthesized ferrites, with the exception of the spray-drying method, are nanocrystalline stoichiometric single-phase powders (Figure 1) with a SSA in the wide range of $30-55 \mathrm{~m}^{2} / \mathrm{g}$ depending on the synthesis method and calculated (average) particle size of 20-40 nm (Table 1, Figure 2). The crystallite size of these ferrites is also in the range of $10-40 \mathrm{~nm}$. During the spraydrying process high-dispersity nanoparticles, mainly consisting of cobalt or nickel ferrite, iron hydroxide $\mathrm{FeO}(\mathrm{OH})$, and X-ray amorphous part of the sample [38] were obtained. The SSA of these samples was in the range of $80-90 \mathrm{~m}^{2} / \mathrm{g}$ (Table 1), but the calculated average particle size was 13-15 nm [38]. In this process, pellets of up to $10 \mu \mathrm{m}$ were obtained (Figure 3).

The finer particles were obtained in the spray-drying process, hydrothermal and sol-gel selfpropagating combustion synthesis, but the distribution of the particle size of ferrites obtained 


\begin{tabular}{|c|c|c|c|c|c|c|c|}
\hline Sample & $\begin{array}{l}\mathrm{SSA}, \\
\mathrm{m}^{2} / \mathrm{g}\end{array}$ & $\begin{array}{l}d_{50^{\prime}} \\
n^{*}\end{array}$ & $\begin{array}{l}\text { Crystallite size, } \\
\text { nm }\end{array}$ & Phase composition & $\begin{array}{l}M_{s^{\prime}} \\
\mathrm{emu} / \mathrm{g}\end{array}$ & $\begin{array}{l}M_{r^{\prime}} \\
\mathrm{emu} / \mathrm{g}\end{array}$ & $H_{c^{\prime}} \mathrm{Oe}$ \\
\hline $\mathrm{CoFe}_{2} \mathrm{O}_{4}$ (plasma) & 29 & 39 & 40 & $\mathrm{CoFe}_{2} \mathrm{O}_{4}$ & 75.4 & 32.0 & 780 \\
\hline $\mathrm{CoFe}_{2} \mathrm{O}_{4}$ (combust.) & 37 & 31 & 20 & $\mathrm{CoFe}_{2} \mathrm{O}_{4}$ & 53.4 & 20.3 & 1170 \\
\hline $\mathrm{CoFe}_{2} \mathrm{O}_{4}$ (hydrotherm.) & 54 & 21 & $10-12$ & $\mathrm{CoFe}_{2} \mathrm{O}_{4}$ & 50.1 & 12.6 & 390 \\
\hline $\mathrm{CoFe}_{2} \mathrm{O}_{4}$ (spray) & 84 & 14 & - & $\begin{array}{l}\text { p.a. } \mathrm{CoFe}_{2} \mathrm{O}_{4^{\prime}} \\
\mathrm{FeO}(\mathrm{OH})\end{array}$ & - & - & - \\
\hline $\mathrm{NiFe}_{2} \mathrm{O}_{4}$ (plasma) & 29 & 38 & 40 & $\mathrm{NiFe}_{2} \mathrm{O}_{4}$ & 44.2 & 10.0 & 74 \\
\hline $\mathrm{NiFe}_{2} \mathrm{O}_{4}$ (combust.) & 43 & 26 & 10 & $\mathrm{NiFe}_{2} \mathrm{O}_{4}$ & 21.4 & 2.3 & 81 \\
\hline $\mathrm{NiFe}_{2} \mathrm{O}_{4}$ (hydrotherm.) & 42 & 26 & 22 & $\mathrm{NiFe}_{2} \mathrm{O}_{4}$ & 39.0 & 2.6 & 23 \\
\hline $\mathrm{NiFe}_{2} \mathrm{O}_{4}$ (spray) & 85 & 13 & - & $\begin{array}{l}\text { p.a. } \mathrm{NiFe}_{2} \mathrm{O}_{4^{\prime}} \\
\mathrm{FeO}(\mathrm{OH})\end{array}$ & - & - & - \\
\hline
\end{tabular}

*Average particle size calculated from SSA.

p.a. - partially amorphous; $M_{s}$-saturation magnetization; $M_{r}$-remanent magnetization; $H_{c}$ - coercivity

Table 1. Properties of synthesized ferrite nanopowders.

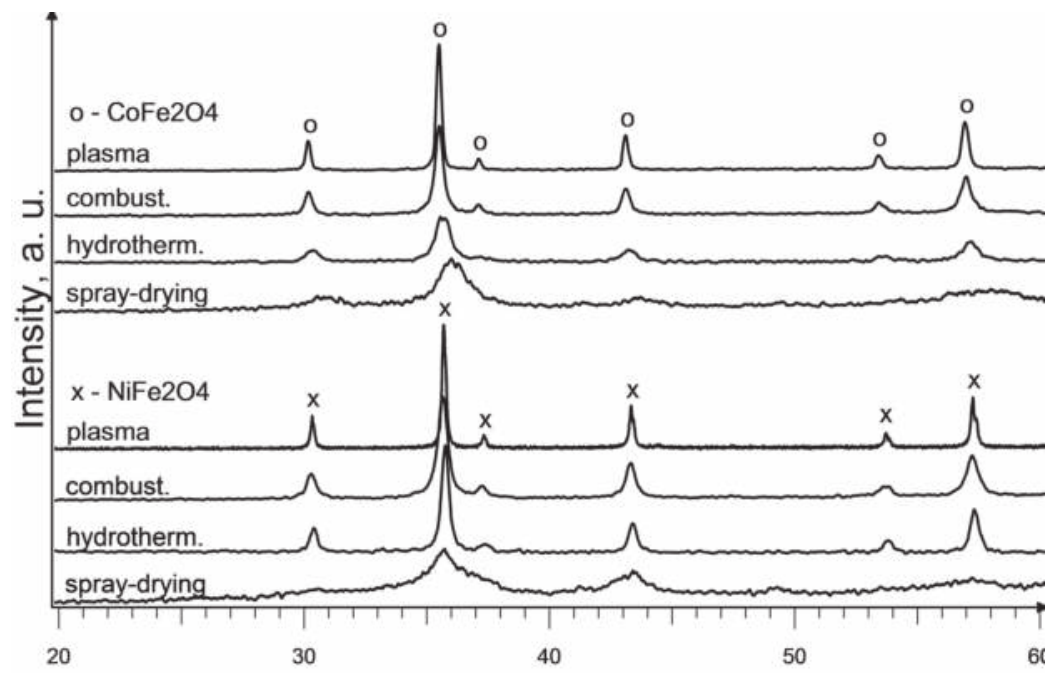

2-Theta

Figure 1. XRD pattern of ferrite nanopowders.

by the plasma synthesis is the most extensive $(20-100 \mathrm{~nm})$ with individual particles up to $200 \mathrm{~nm}$. Plasma-derived particles are spherical.

The samples obtained at the optimal synthesis conditions were very clean because any other additional phase (usually magnetite, maghemite, hematite or other metal oxides) was not found by 

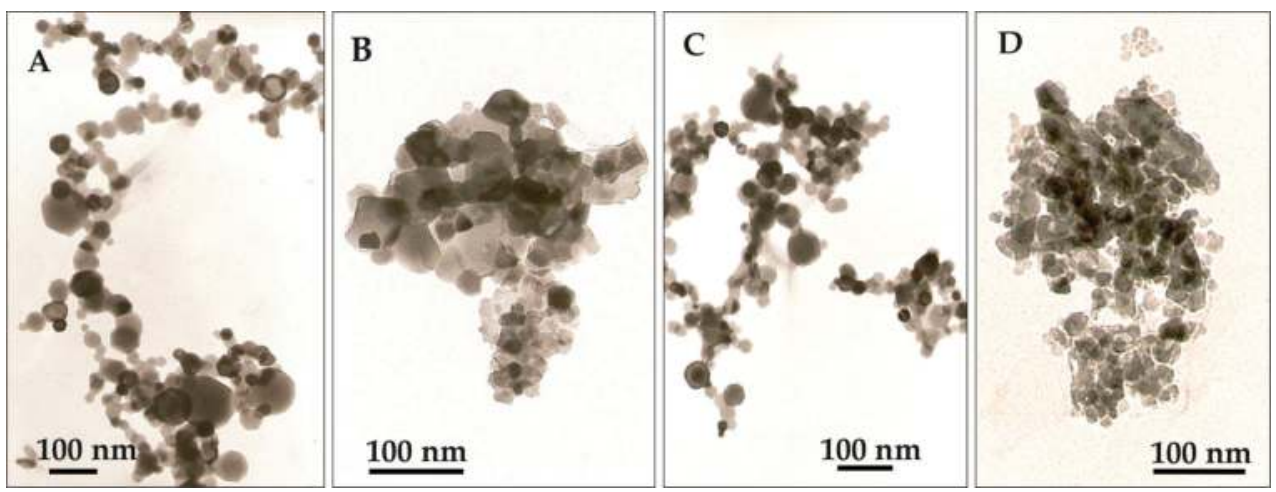

Figure 2. The electron microscope image of $\mathrm{CoFe}_{2} \mathrm{O}_{4}(\mathrm{~A}, \mathrm{C})$ and $\mathrm{NiFe}_{2} \mathrm{O}_{4}(\mathrm{~B}, \mathrm{D})$ obtained by the plasma synthesis (A), self-combustion (B), hydrothermal (C) and spray (D) methods.

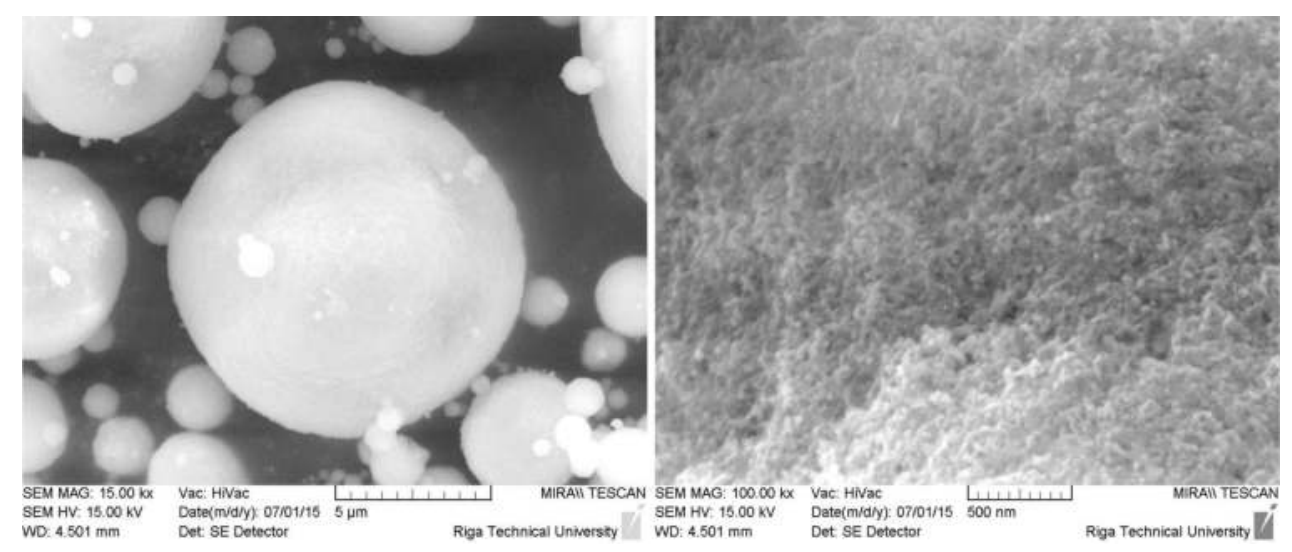

Figure 3. The electron microscope (SEM) images of spray-dried $\mathrm{NiFe}_{2} \mathrm{O}_{4}$ at different enlargements.

the X-ray analysis. By analyzing samples of ferrites produced by different methods, slight differences in relative intensity and width of reflexes, indicating differences in crystallite size (Figure 1), can be seen in the X-ray images. The self-combustion and hydrothermal synthesis methods give nanopowders with a lower crystallite size than those obtained by plasma synthesis (Table 1).

The magnetic properties of the nanoparticles obtained by the plasma synthesis process (Table 1, Figure 4$)$ are very close to those of the standard dense material $\left(\mathrm{CoFe}_{2} \mathrm{O}_{4}\right.$ magnetic saturation values are $80 \mathrm{emu} / \mathrm{g}$ and $\mathrm{NiFe}_{2} \mathrm{O}_{4} 50 \mathrm{emu} / \mathrm{g}$ [40]). In contrast, the samples prepared by selfcombustion and hydrothermal method have different magnetic properties than those obtained by plasma synthesis. This is probably due to difference in the size of nanoparticles obtained by plasma, self-combustion and hydrothermal synthesis. The products obtained by the spray-drying method have magnetic properties only after heat treatment at $400-450^{\circ} \mathrm{C}$ at $550^{\circ} \mathrm{C}$, the saturation magnetization of nickel ferrite is $16.9 \mathrm{emu} / \mathrm{g}$, while for the cobalt ferrite is $51.3 \mathrm{emu} / \mathrm{g}$. 

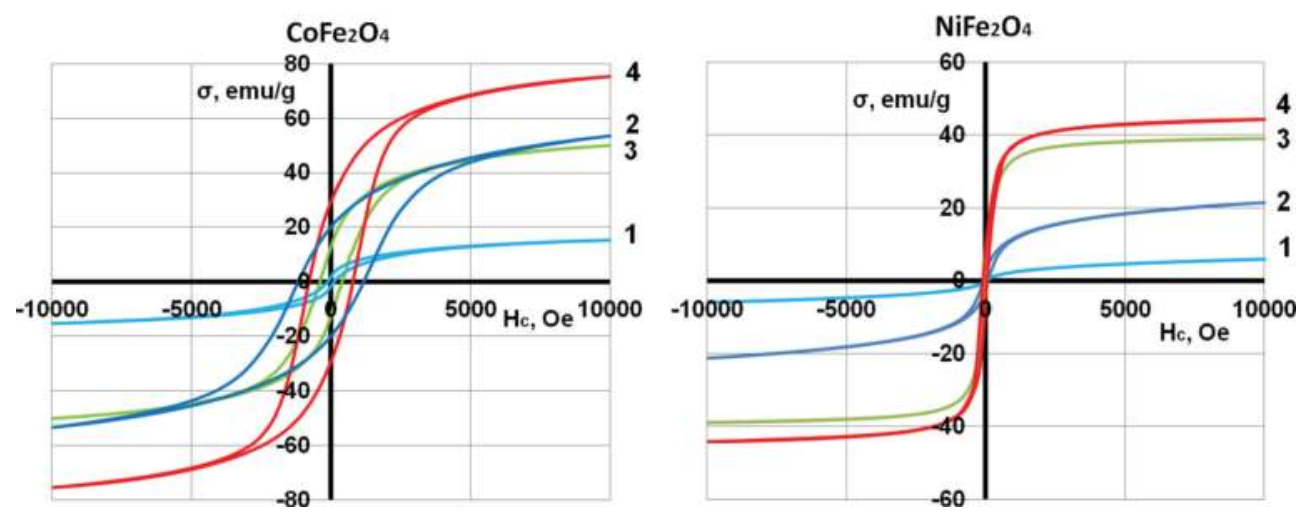

Figure 4. Magnetic properties of ferrites synthesized by the spray-drying (1) at $450^{\circ} \mathrm{C}$, sol-gel self-combustion (2) and hydrothermal (3) method and in plasma (4).

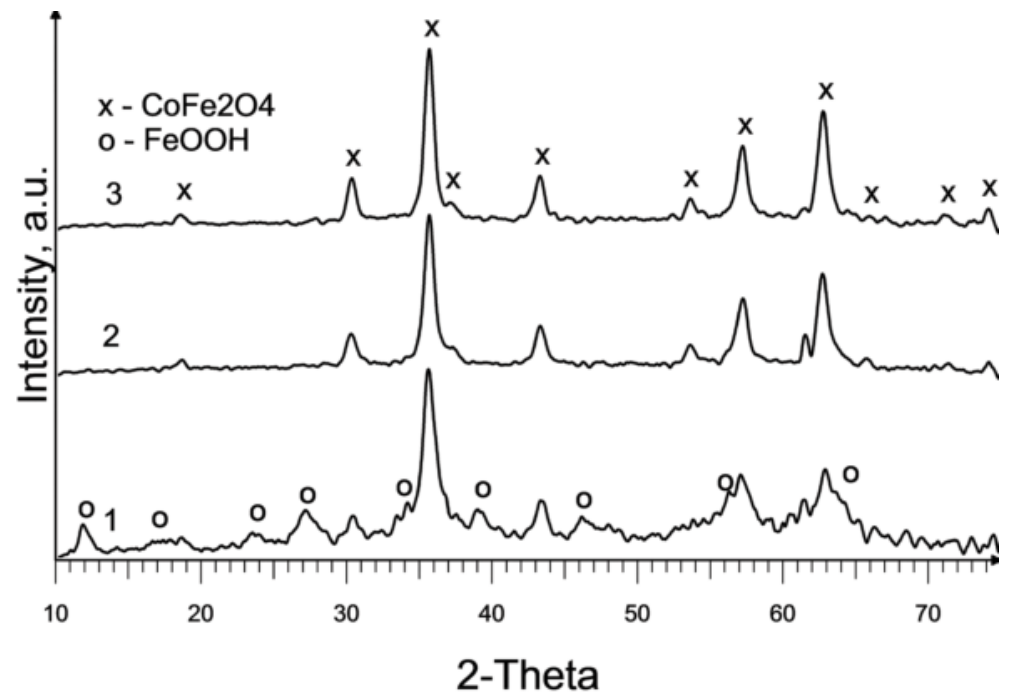

Figure 5. XRD pattern of the hydrothermally synthesized $\mathrm{CoFe}_{2} \mathrm{O}_{4}$ nanopowder prepared at: $1-200^{\circ} \mathrm{C}, 1 \mathrm{~h} ; 2-230^{\circ} \mathrm{C}, 1 \mathrm{~h}$; $3-250^{\circ} \mathrm{C}, 1 \mathrm{~h}$

Another interesting feature of nanoparticles synthesized in this study is their magnetic behavior, that is, although for all synthesized powders the particle size is below the critical size of a single domain (about $70 \mathrm{~nm}$ [41]), quasi-supermagnetic behavior is observed only for plasmasynthesized $\mathrm{NiFe}_{2} \mathrm{O}_{4}$ nanoparticles.

As an example of the impact of synthesis parameters, $\mathrm{CoFe}_{2} \mathrm{O}_{4}$ hydrothermal synthesis can be mentioned. Synthesizing at $200^{\circ} \mathrm{C}$ for $1 \mathrm{~h}$, the product contains also $\mathrm{FeO}(\mathrm{OH})$ in addition to the basic phase (Figure 5). The product has weak magnetic properties (Table 2). Experiments 


\begin{tabular}{|c|c|c|c|c|c|c|c|c|}
\hline \multirow[t]{2}{*}{ No } & \multirow{2}{*}{$\begin{array}{l}\text { Mode, } \\
{ }^{\circ} \mathrm{C} / \mathrm{h}\end{array}$} & \multirow[t]{2}{*}{$\mathrm{SSA}, \mathrm{m}^{2} / \mathrm{g}$} & \multirow{2}{*}{$\mathrm{d}_{50^{\prime}} \mathrm{nm}^{*}$} & \multirow{2}{*}{$\begin{array}{l}\text { Crystallite size, } \\
\text { nm }\end{array}$} & \multirow[t]{2}{*}{ XRD phases } & \multicolumn{3}{|c|}{ Magnetic properties } \\
\hline & & & & & & $\begin{array}{l}M_{s^{\prime}} \\
\mathrm{emu} / \mathrm{g}\end{array}$ & $\mathrm{M}_{\mathrm{r}^{\prime}} \mathrm{emu} / \mathrm{g}$ & $\mathrm{H}_{\mathrm{c}^{\prime}} \mathrm{Oe}$ \\
\hline 1 & $200 / 1$ & 58 & 20 & $\sim 10$ & $\mathrm{CoFe}_{2} \mathrm{O}_{4}, \mathrm{FeO}(\mathrm{OH})$ & 13.2 & 2.6 & 105 \\
\hline 2 & $200 / 3$ & 59 & 19 & $13-14$ & $\mathrm{CoFe}_{2} \mathrm{O}_{4}$ & - & - & - \\
\hline 3 & $230 / 1$ & 63 & 18 & $10-13$ & $\mathrm{CoFe}_{2} \mathrm{O}_{4}$ & 50.0 & 10.2 & 494 \\
\hline 4 & $230 / 3$ & 55 & 21 & $15-16$ & $\mathrm{CoFe}_{2} \mathrm{O}_{4}$ & 58.9 & 17.8 & 643 \\
\hline 5 & $250 / 1$ & 61 & 19 & $12-13$ & $\mathrm{CoFe}_{2} \mathrm{O}_{4}$ & 57.3 & 17.3 & 566 \\
\hline 6 & $250 / 3$ & 62 & 18 & $10-12$ & $\mathrm{CoFe}_{2} \mathrm{O}_{4}$ & 59.8 & 16.8 & 574 \\
\hline
\end{tabular}

Table 2. Characteristics of $\mathrm{CoFe}_{2} \mathrm{O}_{4}$ nanopowders prepared hydrothermally.

have shown that the optimum synthesis temperature, when the pure one-phase product is formed, is from $230^{\circ} \mathrm{C}$. Increasing the processing temperatures (up to $250^{\circ} \mathrm{C}$ ) and time (up to $3 \mathrm{~h}$ ) does not significantly affect the size of the specific surface area and crystallite. Increasing of the synthesis temperature and hydrothermal treatment time results in a small increase in magnetic characteristics (saturation magnetization $\mathrm{M}_{\mathrm{s}^{\prime}}$ remanent magnetization $\mathrm{M}_{\mathrm{r}}$ and coercivity $\left.\mathrm{H}_{\mathrm{c}}\right)($ Table 2).

After thermal treatment at higher temperatures, ferrite nanopowders synthesized by selfcombustion, hydrothermal and spray-drying method, tend to decrease their SSA, but the particle size and crystallite size increase (Figure 6). This trend can be explained by the fact that the particles recrystallize and grow at higher temperatures, so the specific surface decreases. With the increase of crystallite size, the saturation magnetization and remanent magnetization of ferrites increase (Tables 3 and 4, Figures 7 and 8). For example, after thermal treatment of $\mathrm{CoFe}_{2} \mathrm{O}_{4}$ obtained by self-combustion and hydrothermal method at $800^{\circ} \mathrm{C}$ and more, the saturation magnetization increases to 80 and $72 \mathrm{emu} / \mathrm{g}$, respectively.
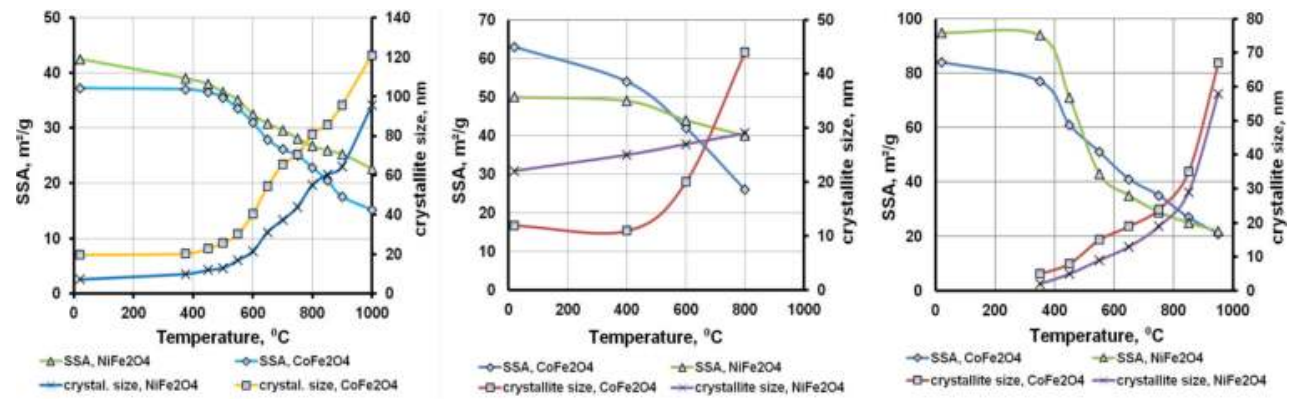

Figure 6. Specific surface area (SSA) and crystallite size comparison depending on temperature for $\mathrm{NiFe}_{2} \mathrm{O}_{4}$ and $\mathrm{CoFe}_{2} \mathrm{O}_{4}$ synthesized by the sol-gel self-combustion (A), the hydrothermal (B) and spray-drying (C) method. 


\begin{tabular}{lllll}
\hline Samples & Heating temperature, ${ }^{\circ} \mathbf{C}$ & $\mathbf{M}_{\mathbf{s}^{\prime}} \mathbf{e m u} / \mathbf{g}$ & $\mathbf{M}_{\mathbf{r}^{\prime}} \mathbf{e m u} / \mathbf{g}$ & $\mathbf{H}_{\mathbf{c}^{\prime}} \mathbf{O e}$ \\
\hline $\mathrm{CoFe}_{2} \mathrm{O}_{4}$ combust. & Raw powder & 53.4 & 20.3 & 1170 \\
& 450 & 55.0 & 21.7 & 1190 \\
& 650 & 76.1 & 39.3 & 1350 \\
& 850 & 79.9 & 35.7 & 930 \\
& 900 & 79.8 & 31.3 & 980 \\
$\mathrm{CoFe}_{2} \mathrm{O}_{4}$ hydrotherm. & Raw powder & 50.0 & 10.2 & 495 \\
& 400 & 50.1 & 12.6 & 390 \\
& 600 & 62.8 & 22.4 & 760 \\
$\mathrm{CoFe}_{2} \mathrm{O}_{4}$ spray & 800 & 71.6 & 28.9 & 875 \\
& Raw powder & - & - & - \\
& 350 & - & - & - \\
& 550 & 51.3 & 14.7 & 649 \\
& 750 & 61.1 & 22.3 & 878 \\
& 950 & 76.8 & 34.1 & 1067 \\
\hline
\end{tabular}

Table 3. Magnetic properties of $\mathrm{CoFe}_{2} \mathrm{O}_{4}$ synthesized by the sol-gel self-combustion, hydrothermal and spray-drying methods after thermal treatment ( $2 \mathrm{~h}$ at different temperatures).

The spray-dried powder after the synthesis and granulation is partially amorphous and contains a small amount of $\mathrm{FeO}(\mathrm{OH})$. After heat treatment, starting from 400 to $450^{\circ} \mathrm{C}$, a stoichiometric, single-phase nanocrystalline powder $\left(\mathrm{NiFe}_{2} \mathrm{O}_{4}\right.$ or $\left.\mathrm{CoFe}_{2} \mathrm{O}_{4}\right)$ (Figure 9) was formed, with SSA from 100 (at $350^{\circ} \mathrm{C}$ ) to $20 \mathrm{~m}^{2} / \mathrm{g}$ (at $950^{\circ} \mathrm{C}$ ) (Figure 6). The crystallite size at $350^{\circ} \mathrm{C}$ is 4 and $6 \mathrm{~nm}$, respectively for $\mathrm{NiFe}_{2} \mathrm{O}_{4}$ and $\mathrm{CoFe}_{2} \mathrm{O}_{4}$, which increases with the increase of the processing temperature. The saturation magnetization $\left(\mathrm{M}_{\mathrm{s}}\right)$ of the $\mathrm{NiFe}_{2} \mathrm{O}_{4}$ and $\mathrm{CoFe}_{2} \mathrm{O}_{4}$ ferrites increases, respectively, from 6 and $15 \mathrm{emu} / \mathrm{g}\left(\right.$ at $450^{\circ} \mathrm{C}$ ) to 40 and $77 \mathrm{emu} / \mathrm{g}$ (at $950^{\circ} \mathrm{C}$ ) (Tables 3 and 4, Figure 8).

The relative density of samples before sintering was of $51-52 \%$ for plasma synthesized products and of $31-33 \%$ for products obtained by other methods. This shows that the ferrite nanopowders obtained by these methods are more difficult to compress because their particles are finer than ferrite powders synthesized in plasma.

Nanosized ferrite powders were sinteredat $900-1300^{\circ} \mathrm{C}$. The density of ferrites after the heat treatment is shown in Table 5.

The sintering process of plasma synthesis products is the fastest compared with all investigated nanopowders: they have a high density at $900^{\circ} \mathrm{C}$, but above $1000^{\circ} \mathrm{C}$, the density is approaching already $100 \%$. $\mathrm{CoFe}_{2} \mathrm{O}_{4}$ ferrites synthesized by other methods have a relatively high density at $1100^{\circ} \mathrm{C}$, while $\mathrm{NiFe}_{2} \mathrm{O}_{4}$ ferrites require the temperature of $1200^{\circ} \mathrm{C}$ or higher to achieve high density. Although the sintering temperature of the ferrites obtained by the 


\begin{tabular}{lllll}
\hline Samples & Heating temperature, ${ }^{\circ} \mathbf{C}$ & $\mathbf{M}_{\mathbf{s}^{\prime}}$ emu/g & $\mathbf{M}_{\mathbf{r}^{\prime}}$ emu/g & $\mathbf{H}_{\mathbf{c}^{\prime}} \mathbf{O e}$ \\
\hline $\mathrm{NiFe}_{2} \mathrm{O}_{4}$ combust. & Raw powder & 29.0 & 6.0 & 120 \\
& 450 & 31.4 & 4.8 & 130 \\
& 650 & 37.4 & 9.1 & 200 \\
& 850 & 45.2 & 14.8 & 145 \\
& 900 & 47.4 & 15.0 & 135 \\
$\mathrm{NiFe}_{2} \mathrm{O}_{4}$ hydrotherm. & Raw powder & 37.4 & 2.6 & 23 \\
& 400 & 36.7 & 3.8 & 34 \\
& 600 & 40.2 & 5.2 & 55 \\
$\mathrm{NiFe}_{2} \mathrm{O}_{4}$ spray & 800 & 42.6 & 5.0 & 70 \\
& Raw powder & - & - & - \\
& 350 & - & - & - \\
& 550 & 16.9 & 1.1 & 57 \\
& 750 & 21.6 & 4.5 & 214 \\
& 950 & 40.0 & 8.6 & 151 \\
\hline
\end{tabular}

Table 4. Magnetic properties of $\mathrm{NiFe}_{2} \mathrm{O}_{4}$ synthesized by the sol-gel self-combustion, hydrothermal and spray-drying methods after thermal treatment ( $2 \mathrm{~h}$ at different temperatures).
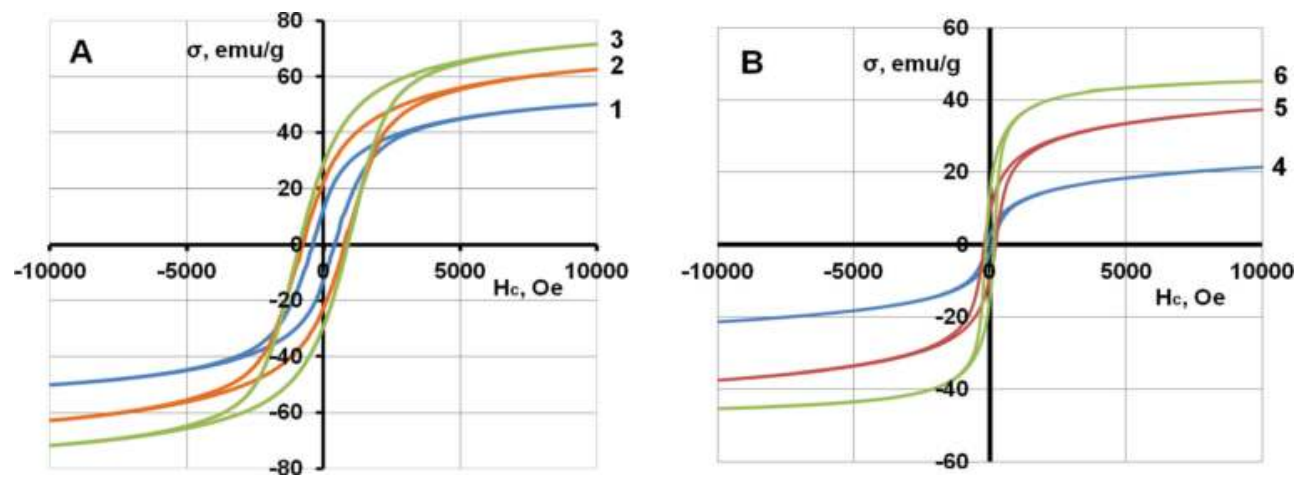

Figure 7. The magnetic properties of the sample $\mathrm{CoFe}_{2} \mathrm{O}_{4}$ prepared by the hydrothermal synthesis (A) after thermal treatment at $400^{\circ} \mathrm{C}(1), 600^{\circ} \mathrm{C}(2)$ and $800^{\circ} \mathrm{C}(3), \mathrm{NiFe}_{2} \mathrm{O}_{4}$ prepared by the self-combustion synthesis (B) after thermal treatment at $450^{\circ} \mathrm{C}(4), 650^{\circ} \mathrm{C}(5)$ and $850^{\circ} \mathrm{C} \mathrm{(6)}$.

spray method is slightly higher, they could be the most promising on the technological point of view among all these nanopowders because they are flowing and can be pressed without further treatment. 

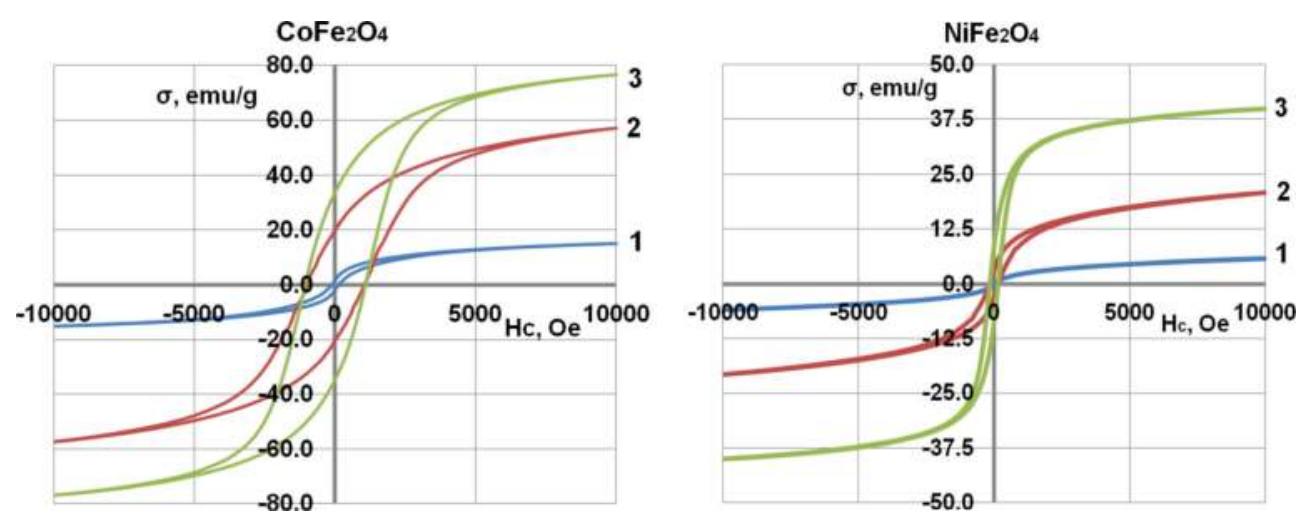

Figure 8. The magnetic properties of samples of $\mathrm{CoFe}_{2} \mathrm{O}_{4}$ and $\mathrm{NiFe}_{2} \mathrm{O}_{4}$ after thermal treatment at 450 (1), 650 (2) and 950 $(3)^{\circ} \mathrm{C}$ prepared by the spray-drying method.
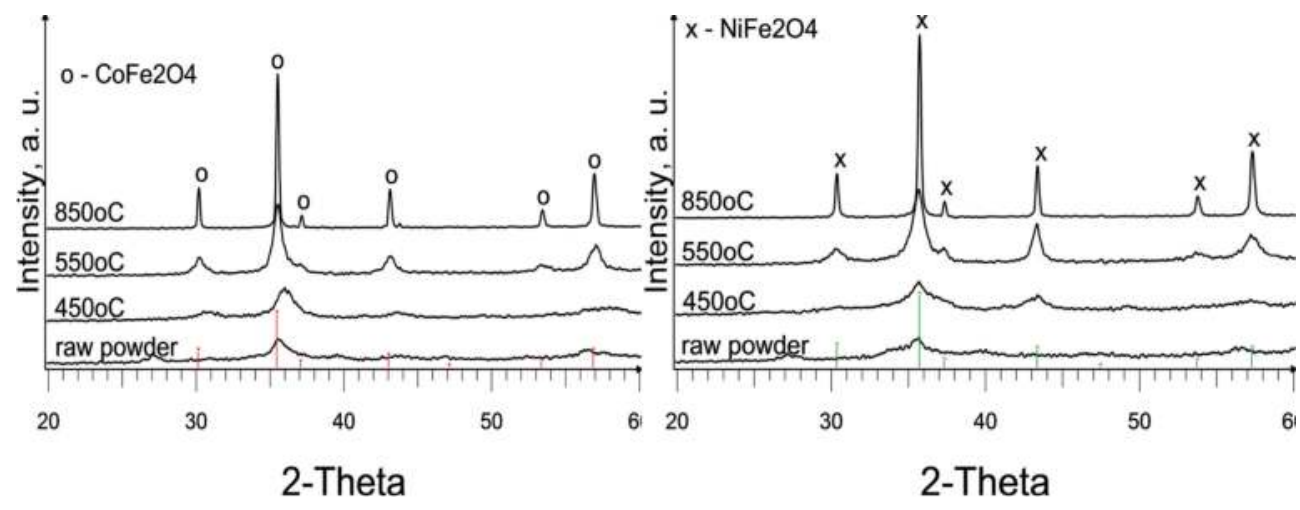

Figure 9. XRD pattern of spray-dried $\mathrm{CoFe}_{2} \mathrm{O}_{4}$ and $\mathrm{NiFe}_{2} \mathrm{O}_{4}$ ferrite nanopowders.

The crystallite size grows slightly during sintering: from 70 to $80 \mathrm{~nm}$ at $1100^{\circ} \mathrm{C}$ to 120 $140 \mathrm{~nm}$ at $1300^{\circ} \mathrm{C}$. For example, the crystallite size of hydrothermal $\mathrm{CoFe}_{2} \mathrm{O}_{4}$ varies from 10 to $13 \mathrm{~nm}$ in the raw powder to $75 \mathrm{~nm}\left(1000^{\circ} \mathrm{C}\right)$ and $150 \mathrm{~nm}$ (sintered at $\left.1200^{\circ} \mathrm{C}\right)$. The grain size of samples sintered at $1200^{\circ} \mathrm{C}$, obtained from self-combustion, hydrothermal and spraydried powders, does not exceed 1 to $6 \mu \mathrm{m}$ (Figure 10). As a result of high sintering activity, the grain size of plasma-synthesized ferrite outweighs: $10-15 \mu \mathrm{m}$ for $\mathrm{NiFe}_{2} \mathrm{O}_{4}$ and $10-30 \mu \mathrm{m}$ for $\mathrm{CoFe}_{2} \mathrm{O}_{4}$.

Compared with the ferrite nanopowders, ceramic materials have a higher saturation magnetization (Figure 11) and lower coercivity. This could be explained by the increase in grain size and crystallite size. An increase in the temperature of the sintering results in the increase of the grain size and magnetization for all ferrite materials, while coercivity decreases (Table 6). 


\begin{tabular}{|c|c|c|c|c|c|c|c|c|c|c|}
\hline \multirow[t]{3}{*}{ Sample } & \multicolumn{10}{|c|}{ Sintering temperature, ${ }^{\circ} \mathrm{C}$} \\
\hline & \multicolumn{2}{|l|}{900} & \multicolumn{2}{|l|}{1000} & \multicolumn{2}{|l|}{1100} & \multicolumn{2}{|l|}{1200} & \multicolumn{2}{|l|}{1300} \\
\hline & $\varrho, \%$ & $P_{\text {op. }} \%$ & $\mathrm{Q}, \%$ & $P_{\text {op. }} \%$ & $\varrho, \%$ & $P_{\text {op. }} \%$ & $\varrho, \%$ & $P_{\text {op. }} \%$ & $\varrho, \%$ & $P_{\text {op. }} \%$ \\
\hline $\mathrm{CoFe}_{2} \mathrm{O}_{4}$ (plasma) & 82.6 & 16.0 & 97.0 & 0.2 & 98.5 & 0.1 & 97.9 & 0 & - & - \\
\hline $\mathrm{CoFe}_{2} \mathrm{O}_{4}$ (combust.) & - & - & 65.7 & 33.4 & 78.3 & 21.6 & 93.4 & 3.1 & - & - \\
\hline $\mathrm{CoFe}_{2} \mathrm{O}_{4}$ (hydrotherm.) & - & - & 81.3 & 14.2 & 94.3 & 0.8 & 95.0 & 0.1 & - & - \\
\hline $\mathrm{CoFe}_{2} \mathrm{O}_{4}$ (spray) & - & - & 62.3 & 35.5 & 90.0 & 8.8 & 90.8 & 4.7 & 95.1 & 0.7 \\
\hline $\mathrm{NiFe}_{2} \mathrm{O}_{4}$ (plasma) & 87.9 & 12.1 & 99.4 & 0.2 & 99.9 & 0.1 & 100.0 & 0 & - & - \\
\hline $\mathrm{NiFe}_{2} \mathrm{O}_{4}$ (combust.) & - & - & 72.4 & 25.5 & 87.7 & 9.4 & 96.1 & 1.6 & - & - \\
\hline $\mathrm{NiFe}_{2} \mathrm{O}_{4}$ (hydrotherm.) & - & - & - & - & 79.1 & 19.8 & 85.8 & 12.0 & - & - \\
\hline $\mathrm{NiFe}_{2} \mathrm{O}_{4}$ (spray) & - & - & 52.2 & 44.0 & 69.5 & 27.6 & 85.3 & 12.1 & 90.7 & 7.1 \\
\hline
\end{tabular}

Q-density; $\mathrm{P}_{\mathrm{op}}$-open porosity.

Table 5. The relative density and open porosity of ferrites depending on sintering temperature (after $2 \mathrm{~h}$ sintering).
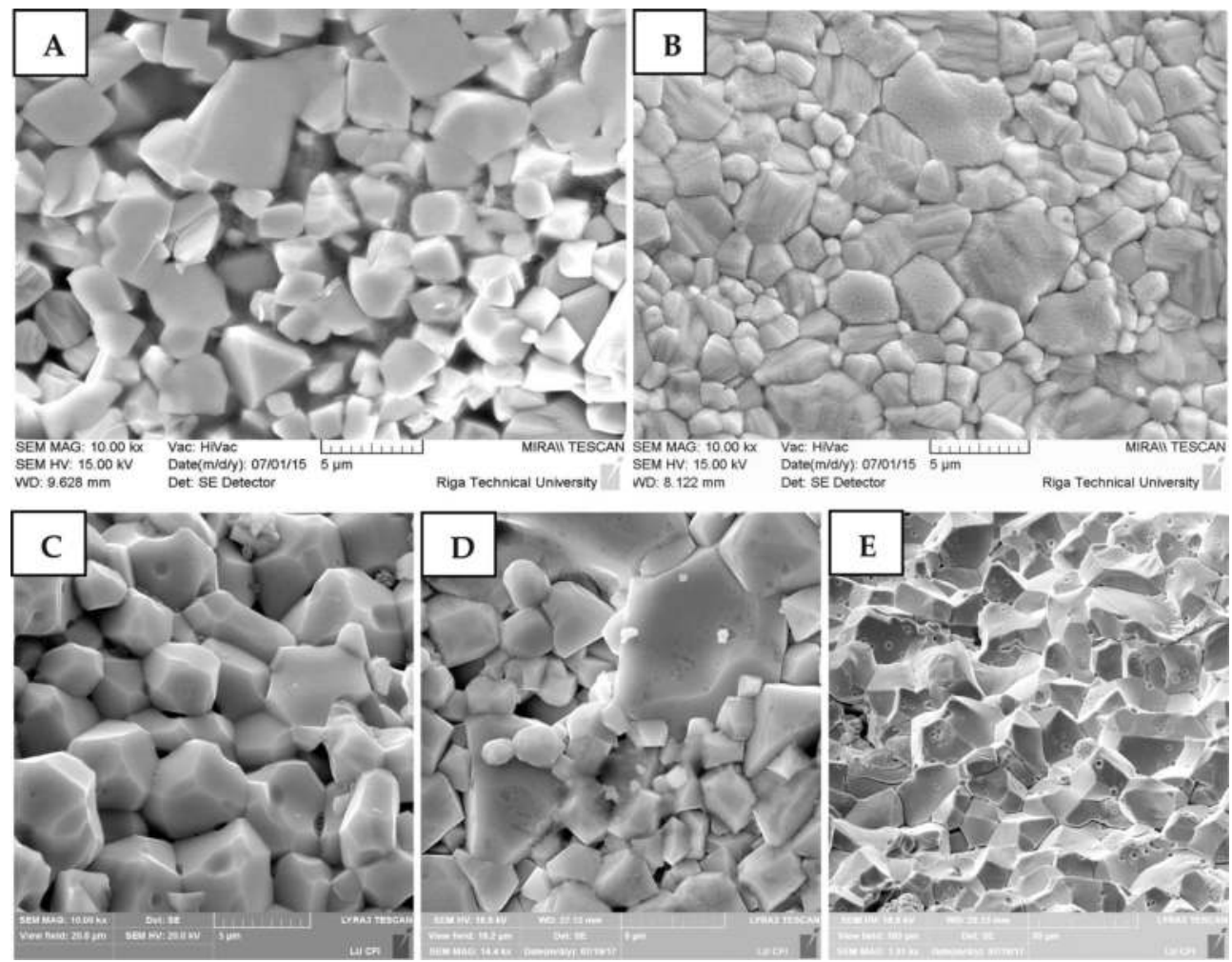

Figure 10. Typical SEM image of $\mathrm{NiFe}_{2} \mathrm{O}_{4}(\mathrm{a}, \mathrm{D})$ and $\mathrm{CoFe}_{2} \mathrm{O}_{4}(\mathrm{~B}, \mathrm{C}, \mathrm{E})$ ceramics sintered at $1200^{\circ} \mathrm{C} 2 \mathrm{~h}$. The powders are prepared by hydrothermal (A, B), sol-gel self-propagating combustion (C), spray-drying (D) and plasma (E) methods. 

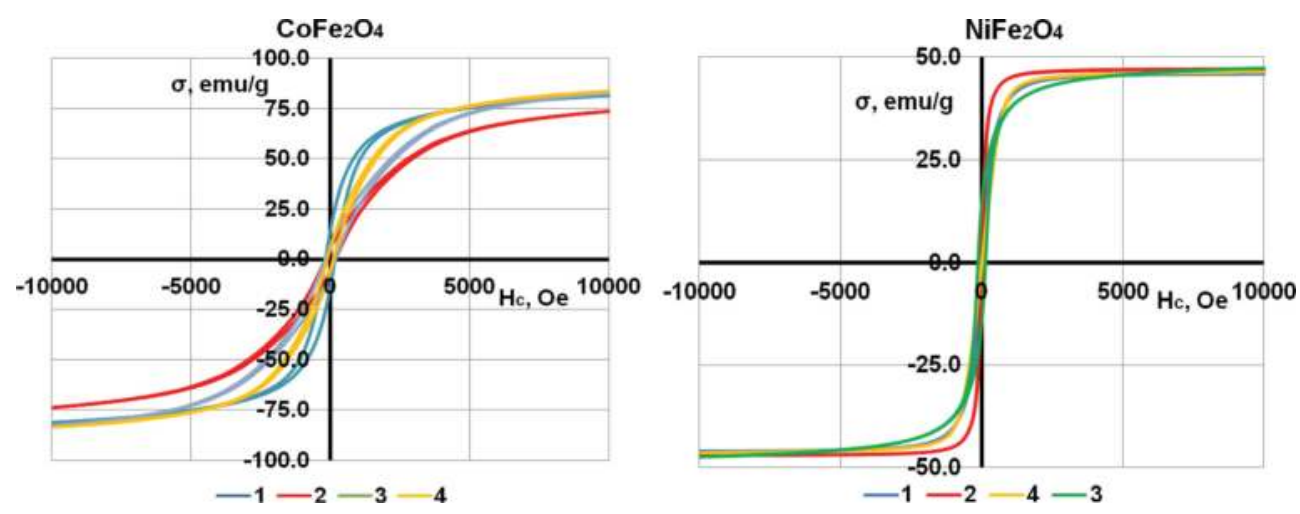

Figure 11. Magnetic properties of $\mathrm{CoFe}_{2} \mathrm{O}_{4}$ (a) and $\mathrm{NiFe}_{2} \mathrm{O}_{4}$ (B) ferrite, sintered at $1200^{\circ} \mathrm{C}$ from different powders: $1-$ hydrothermal, 2-spray-drying, 3-combustion, 4-plasma.

\begin{tabular}{|c|c|c|c|c|c|c|}
\hline \multirow[t]{2}{*}{ Heating temperature, ${ }^{\circ} \mathrm{C}$} & \multicolumn{3}{|l|}{$\mathrm{CoFe}_{2} \mathrm{O}_{4}$} & \multicolumn{3}{|l|}{$\mathrm{NiFe}_{2} \mathrm{O}_{4}$} \\
\hline & $\mathrm{M}_{\mathrm{s}^{\prime}} \mathrm{emu} / \mathrm{g}$ & $\mathrm{M}_{\mathrm{r}^{\prime}} \mathrm{emu} / \mathrm{g}$ & $\mathrm{H}_{\mathrm{c}^{\prime}} \mathrm{Oe}$ & $\mathbf{M}_{\mathrm{s}^{\prime}} \mathrm{emu} / \mathrm{g}$ & $M_{r^{\prime}} \mathrm{emu} / \mathrm{g}$ & $\mathrm{H}_{\mathrm{c}^{\prime}} \mathrm{Oe}$ \\
\hline \multicolumn{7}{|l|}{ Self-combustion } \\
\hline 1200 & 82.6 & 6.9 & 190 & - & - & - \\
\hline \multicolumn{7}{|l|}{ Hydrothermal } \\
\hline 1100 & 77.0 & 20.7 & 493 & 40.4 & 6.5 & 102 \\
\hline 1200 & 81.3 & 14.1 & 169 & 46.0 & 1.7 & 15 \\
\hline \multicolumn{7}{|l|}{ Spray } \\
\hline 1100 & 74.6 & 15.3 & 427 & 48.0 & 3.0 & 35 \\
\hline 1300 & 73.8 & 5.9 & 187 & 47.0 & 2.4 & 11 \\
\hline \multicolumn{7}{|l|}{ Plasma } \\
\hline 1100 & 81.8 & 14.0 & 258 & 45.7 & 3.8 & 35 \\
\hline 1200 & 83.6 & 8.0 & 110 & 46.3 & 0.7 & 11 \\
\hline
\end{tabular}

Table 6. Magnetic properties of $\mathrm{CoFe}_{2} \mathrm{O}_{4}$ and $\mathrm{NiFe}_{2} \mathrm{O}_{4}$ ceramics after $2 \mathrm{~h}$ sintering.

The magnetic properties of the samples sintered at $1200^{\circ} \mathrm{C}$ are almost the same regardless of the method of extracting ferrite powders: saturation magnetization for $\mathrm{CoFe}_{2} \mathrm{O}_{4}$ is of 80-84 emu/g and 46-48 emu/g for $\mathrm{NiFe}_{2} \mathrm{O}_{4}$.

\section{Conclusions}

Single-phase nickel and cobalt ferrite nanopowders can be successfully synthesized by the chemical sol-gel self-propagating combustion and co-precipitation method combined with 
hydrothermal synthesis or spray-drying method as well as high-frequency plasma synthesis. The magnetic properties of synthesized ferrite powders depend on their synthesis method.

Comparing the methods for obtaining ferrite nanopowders described earlier, we can say that plasma synthesis currently is the most productive method resulting in the highest magnetic properties (75 emu/g for $\mathrm{CoFe}_{2} \mathrm{O}_{4}$ and $44 \mathrm{emu} / \mathrm{g}$ for $\mathrm{NiFe}_{2} \mathrm{O}_{4}$ ). The disadvantage of this method is the presence of particles exceeding the size of $100 \mathrm{~nm}$ in a product that is not acceptable in all applications.

The chemical sol-gel self-propagating combustion and hydrothermal synthesis methods enables the production of smaller particles (SSA $=35-55 \mathrm{~m}^{2} / \mathrm{g}$; average particle size $20-30 \mathrm{~nm}$ ) with less explicited magnetic properties (50-55 emu/g for $\mathrm{CoFe}_{2} \mathrm{O}_{4}$ and $20-40 \mathrm{emu} / \mathrm{g}$ for $\mathrm{NiFe}_{2} \mathrm{O}_{4}$ ) after synthesis, which can be increased after heat treatment at temperatures up to $800^{\circ} \mathrm{C}$. The lack of these methods is a time-consuming process of filtering nanoparticles.

The filtration process can be bypassed by the spray-drying method. Here, the smallest particles of the powder (SSA $=80-90 \mathrm{~m}^{2} / \mathrm{g}$, average particle size $10-15 \mathrm{~nm}$ ) are obtained, but due to the low processing temperatures, they have no explicited magnetic properties. Magnetic properties are observed after additional treatment starting at $400-450^{\circ} \mathrm{C}$. However, the granular product is well suited for automated pressing processes for production of ceramic materials.

Sintered materials have higher magnetic properties than nanopowders. Magnetic properties of samples sintered at $1200^{\circ} \mathrm{C}$ are almost the same regardless of the method of obtaining ferrite powders: the saturation magnetization of $\mathrm{CoFe}_{2} \mathrm{O}_{4}$ is $80-84 \mathrm{emu} / \mathrm{g}$ and $46-48 \mathrm{emu} / \mathrm{g}$ for $\mathrm{NiFe}_{2} \mathrm{O}_{4}$.

\section{Author details}

Ilmars Zalite ${ }^{1 *}$, Gundega Heidemane ${ }^{1}$, Janis Grabis ${ }^{1}$ and Mikhail Maiorov ${ }^{2}$

*Address all correspondence to: ilmars.zalite@rtu.lv

1 Institute of Inorganic Chemistry, Riga Technical University, Riga, Latvia

2 Institute of Physics, University of Latvia, Salaspils, Latvia

\section{References}

[1] Costa ACFM, Tortella E, Morelli MR, Kiminami RHGA. Synthesis, microstructure and magnetic properties of $\mathrm{Ni}-\mathrm{Zn}$ ferrites. Journal of Magnetism and Magnetic Materials. 2003;256:174-182. DOI: 10.1016/S0304-8853(02)00449-3

[2] Priyadharsini P, Pradeep A, Chandrasekaran G. Novel combustion route of synthesis and characterization of nanocrystalline mixed ferrites of Ni-Zn. Journal of Magnetism and Magnetic Materials. 2009;321:1898-1903. DOI: 10.1016/j.jmmm.2008.12.005

[3] Hou C, Yu H, Zhang Q, Li Y. WangH. Preparation and magnetic property analysis of monodisperse Co-Zn ferrite nanospheres. Journal of Alloys and Compounds. 2010;491:431-435. DOI: 10.1016/j.jallcom.2009.10.217 
[4] Gul IH, Ahmed W, Maqsood A. Electrical and magnetic characterization of nanocrystalline $\mathrm{Ni}-\mathrm{Zn}$ ferrite synthesis by co-precipitation route. Journal of Magnetism and Magnetic Materials. 2008;320:270-275. DOI: 10.1016/j.jmmm.2007.05.032

[5] Yadoji P, Peelamedu R, Agrawal D, Roy R. Microwave sintering of Ni-Zn ferrites: Comparison with conventional sintering. Materials Science and Engineering: B. 2003;98:269-278. DOI: 10.1016/S0921-5107(03)00063-1

[6] Jadhav SS, Patange SM, Jadhav KM. Dielectric behaviour study of nanocrystalline Co-Zn ferrite. Journal of Biomedical and Bioengineering. 2010;1:21-29

[7] Ahmed MA, EL-Khawlani AA. Enhancement of the crystal size and magnetic properties of Mg-substituted Co ferrite. Journal of Magnetism and Magnetic Materials. 2009;321:1959-1963. DOI: 10.1016/j.jmmm.2008.12.021

[8] Gul IH, Abbasi AZ, Amin F, Anis-ur-Rehman M, Maqsood A. Structural, magnetic and electrical properties of $\mathrm{Co}_{1-x} \mathrm{Zn}_{x} \mathrm{Fe}_{2} \mathrm{O}_{4}$ synthesized by co-precipitation method. Journal of Magnetism and Magnetic Materials. 2007;311:494-499. DOI: 10.1016/j.jmmm.2006.08.005

[9] Xue B, Liu R, Xu ZD, Zheng YF. Microwave Fabrication and Magnetic Property of Hierarchical Spherical $\alpha-\mathrm{Fe}_{2} \mathrm{O}_{3}$ Nanostructures. Chemistry Letters. 2008;37:1058-1059. DOI: $10.1246 / \mathrm{cl} .2008 .1058$

[10] Fortin JP, Wilhelm C, Servais J, Menager C, Bacri JCF, Gazeau J. Size sorted anionic iron oxide nanomagnets as colloidal mediators for magnetic hyperthermia. Chemical Society. 2007;129:2628-2635. DOI: 10.1021/ja067457e

[11] Gul IH, Amin F, Abbasi AZ, Anis-ur-Rehman M, Maqsood A. Physical and magnetic characterization of co-precipitated nanosize Co-Ni ferrites. Scripta Materialia. 2007;56:497-500. DOI: 10.1016/j.scriptamat.2006.11.020

[12] Slatineanu T, Iordan AR, Oancea V, Palamaru MN, Dumitru I, Constantin CP, Caltun OF. Magnetic and dielectric properties of Co-Zn ferrite. Materials Science and Engineering: B. 2013;178:1040-1047. DOI: 10.1016/j.mseb.2013.06.014

[13] Arulmurugan R, Jeyadevan B, Vaidyanathan G, Sendhilnathan S. Effect of zinc substitution on $\mathrm{Co}-\mathrm{Zn}$ and $\mathrm{Mn}-\mathrm{Zn}$ ferrite nanoparticles prepared by co-precipitation. Journal of Magnetism and Magnetic Materials. 2005;288:470-477. DOI: 10.1016/j.jmmm.2004.09.138

[14] Tawfik A. Electromechanical properties of $\mathrm{Co}_{0.6} \mathrm{Zn}_{0.4} \mathrm{Fe}_{2} \mathrm{O}_{4}$ ferrite transducer. Journal of Magnetism and Magnetic Materials. 2001;237:283-287. DOI: 10.1016/S0304-8853(01)00466-8

[15] Kumar S, Singh V, Aggarwal S, Mandal UK, Kotnala RK. Monodisperse Co, Zn-Ferrite nanocrystals: Controlled synthesis, characterization and magnetic properties. Journal of Magnetism and Magnetic Materials. 2012;324:3683-3689. DOI: 10.1016/j.jmmm.2012.05.048

[16] Gul IH, Maqsood A. Structural, magnetic and electrical properties of cobalt ferrites prepared by the sol-gel route. Journal of Alloys and Compounds. 2008;465:227-231. DOI: 10.1016/j.jallcom.2007.11.006 
[17] Giri AK, Kirkpatrick EM, Moongkhamklang P, Majetich SA. Photomagnetism and structure in cobalt ferrite nanoparticles. Applied Physics Letters. 2002;80:2341. DOI: $10.1063 / 1.1464661$

[18] Suryanarayana C. Nanocrystalline materials. International Materials Reviews. 1995; 40:41-64. DOI: 10.1179/imr.1995.40.2.41

[19] van der Zaag PJ, Ruigrok JJM, Noordermeer A, van Delden MHWM. The initial permeability of polycrystalline MnZn ferrites: The influence of domain and microstructure. Journal of Applied Physics. 1993;74:4085-4095. DOI: 10.1063/1.354454

[20] Chicinas I. Soft magnetic nanocrystalline powders produced by mechanical alloying routes. Journal of Optoelectronics and Advanced Materials. 2006;8:439-448

[21] Akther Hossain AKM, Tabata H, Kawai T. Magnetoresistive properties of $\mathrm{Zn}_{1-\mathrm{x}} \mathrm{Co}_{\mathrm{x}-\mathrm{x}}$ $\mathrm{Fe}_{2} \mathrm{O}_{4}$ ferrites. Journal of Magnetism and Magnetic Materials. 2008;320:1157-1162. DOI: 10.1016/j.jmmm.2007.11.009

[22] Ferreira TAS, Waerenborgh JC, Mendonça MHRM, Nunes MR, Costaa FM. Structural and morphological characterization of $\mathrm{FeCO}_{2} \mathrm{O}_{4}$ and $\mathrm{CoFe}_{2} \mathrm{O}_{4}$ spinels prepared by a coprecipitation method. Solid State Sciences. 2003;5:383-392. DOI: 10.1016/S1293-2558(03)00011-6

[23] Tang DQ, Zhang DJ, Ai H. Fabrication of magnetic core-shell $\mathrm{CoFe}_{2} \mathrm{O}_{4} / \mathrm{Al}_{2} \mathrm{O}_{3}$ nanoparticles as immobilized metal chelate affinity support for protein adsorption. Chemistry Letters. 2006;35:1238-1239. DOI: 10.1246/cl.2006.1238

[24] Zhou Z, Zhang Y, Wang Z, Wei W, Tang W, Shi J, Xiong R. Electronic structure studies of the spinel $\mathrm{CoFe}_{2} \mathrm{O}_{4}$ by $\mathrm{X}$-ray photoelectron spectroscopy. Applied Surface Science. 2008;254:6972-6975. DOI: 10.1016/j.apsusc.2008.05.067

[25] Duong GV, Hanh N, Linh DV, Groessinger R, Weinberger P, Schafler E, Zehetbauer M. Monodispersed nanocrystalline $\mathrm{Co}_{1-x} \mathrm{Zn}_{x} \mathrm{Fe}_{2} \mathrm{O}_{4}$ particles by forced hydrolysis: Synthesis and characterization. Journal of Magnetism and Magnetic Materials. 2007;311:46-50. DOI: 10.1016/j.jmmm.2006.11.167

[26] Millot N, Gallet SL, Aymes D, Bernard F, Grin Y. Spark plasma sintering of cobalt ferrite nanopowders prepared by coprecipitation and hydrothermal synthesis. Journal of the European Ceramic Society. 2007;27:921-926. DOI: 10.1016/j.jeurceramsoc.2006.04.141

[27] Giri J, Sriharsha T, Bahadur D. Optimization of parameters for the synthesis of nanosized $\mathrm{Co}_{1-\mathrm{x}} \mathrm{Zn}_{\mathrm{x}} \mathrm{Fe}_{2} \mathrm{O}_{4^{\prime}}(0 \leq \mathrm{x} \leq 0.8)$ by microwave refluxing. Journal of Materials Chemistry. 2004;14:875-880. DOI: 10.1039/B310668C

[28] Chau JLH, Hsu MK, Kao CC. Microwave plasma synthesis of Co and SiC-coated Co nanopowders. Materials Letters. 2006;60:947-951. DOI: 10.1016/j.matlet.2005.10.054

[29] Kim CK, Lee JH, Katoh S, Murakami R, Yoshimura M. Synthesis of Co-, Co-Zn and $\mathrm{Ni}-\mathrm{Zn}$ ferrite powders by the microwave-hydrothermal method. Materials Research Bulletin. 2001;36:2241-2250. DOI: 10.1016/S0025-5408(01)00703-6 
[30] Jiang JZ, Wynn P, Mørup S, Okada T, Berry FJ. Magnetic structure evolution in mechanically milled nanostructured $\mathrm{ZnFe}_{2} \mathrm{O}_{4}$ particles. Nanostructured Materials. 1999;12:737740. DOI: 10.1016/S0965-9773(99)00228-7

[31] Hochepied JF, Bonville P, Pileni MP. Nonstoichiometric zinc ferrite nanocrystals: Syntheses and unusual magnetic properties. The Journal of Physical Chemistry B. 2000;104:905-9122. DOI: 10.1021/jp991626i

[32] Shafi KVPM, Gedanken A, Prozorov R, Balogh J. Sonochemical preparation and sizedependent properties of nanostructured $\mathrm{CoFe}_{2} \mathrm{O}_{4}$ particles. Chemistry of Materials. 1998;10:3445-3450. DOI: 10.1021/cm980182k

[33] Jalaly M, Enayati MH, Karimzadeh F, Kameli P. Mechanosynthesis of nanostructured magnetic Ni-Zn ferrite. Powder Technology. 2009;193:150-153. DOI: 10.1016/j. powtec.2009.03.008

[34] Li F, Liu J, Evans DG, Duan X. Stoichiometric synthesis of pure $\mathrm{MFe}_{2} \mathrm{O}_{4}(\mathrm{M}=\mathrm{Mg}$, Co, and $\mathrm{Ni}$ ) spinel ferrites from tailored layered double hydroxide (hydrotalcite-like) precursors. Chemistry of Materials. 2004;16:1597-1602. DOI: 10.1021/cm035248c

[35] Grabis J, Zalite I. Nanosize powders of refractory compounds for obtaining of finegrained ceramic materials. Materials Science Forum. 2007;555:267-272. DOI: 10.4028/ www.scientific.net/MSF.555.267

[36] Zalite I, Heidemane G, Kodols M, Grabis J, Maiorov M. The synthesis, characterization and sintering of nickel and cobalt ferrite nanopowders. Materials Science (Medžigotyra). 2012;18:3-7. DOI: 10.5755/j01.ms.18.1.1332

[37] Zalite I, Heidemane G, Kuznetsova L, Maiorov M. Hydrothermal synthesis of cobalt ferrite nanosized powders. IOP Conference Series: Materials Science and Engineering. 2015;77:5. DOI: 10.1088/1757-899X/77/1/012011

[38] Zalite I, Heidemane G, Palcevskis E, Maiorov M. Properties of nanosized ferrite powders and sintered materials prepared by the Co-precipitation technology, combined with the spray-drying method. Key Engineering Materials. 2016;721:295-299. DOI: 10.4028/www. scientific.net/KEM.721.295

[39] Zalite I, Heidemane G, Kuznetsova L, Kodols M, Grabis J, Maiorov M. The synthesis and characterization of nickel and cobalt ferrite nanopowders obtained by different methods. Chemical Technology. 2016;67:53-57. DOI: 10.5755/j01.ct.67.1.15824

[40] Smit J, Wijn HPJ. Ferrites: Physical properties of ferrimagnetic oxides in relation to their technical applications. Eindhoven, The Netherlands: Philips Technical Library; 1959. p. 384

[41] Song Q, Zhang ZJ. Correlation between spin-orbital coupling and the superparamagnetic properties in magnetite and cobalt ferrite spinel nanocrystals. Journal of Physical Chemistry B. 2006;110:11205-11209. DOI: 10.1021/jp060577o 
